\title{
Research Article \\ Characterizations of a Food Decapeptide Chelating with Zn(II)
}

\author{
Weiwei Fan ${ }^{1,2}$, Zhenyu Wang ${ }^{1}$, Zhishen $\mathrm{Mu}^{3}$, Ming Du ${ }^{1}$, Lianzhou Jiang ${ }^{4}$, Hesham R. EI-Seedii, ${ }^{5,6}$ Cong Wang ${ }^{1,3, *}$ \\ ${ }^{1}$ Center of Experimental Instrument, School of Food Science and Technology, Dalian Polytechnic University, Dalian 116034, China \\ ${ }^{2}$ School of Bioengineering, Dalian University of Technology, Dalian 116024, China \\ ${ }^{3}$ Inner Mongolia Mengniu Dairy Industry (Group) Co., Ltd., Hohhot 010000, China \\ ${ }^{4}$ College of Food Science, Northeast Agricultural University, Harbin 150030, China \\ ${ }^{5}$ Pharmacognosy Group, Department of Medicinal Chemistry, Uppsala University, Biomedical Centre, Uppsala 75 123, Sweden \\ ${ }^{6}$ International Research Center for Food Nutrition and Safety, Jiangsu University, Zhenjiang, 212013, China
}

\section{ARTICLE INFO}

Article History

Received 14 May 2020

Accepted 20 July 2020

\section{Keywords}

Peptide

zinc

binding sites

molecular docking

structure

\begin{abstract}
Walnut proteins and peptides have been reported to have great zinc-carrying activity. In this study, the decapeptide EPNGLLLPQY (WP-10) derived from walnut protein has been prepared to figure out zinc binding mechanisms and structureactivity relationships. The space-conformation of this peptide has converted after being chelated with $\mathrm{Zn}(\mathrm{II})$. As to secondary structure, the $\beta$-sheet structure of the peptide turned into $\alpha$-helix and $\beta$-turn structure. According to the atomic absorption spectra analysis, one peptide could bind with one $\mathrm{Zn}$ (II) via four different binding sites. The signals of different groups in infrared spectroscopy have shifted before and after chelation, and the major functional groups of this peptide involved in chelation are $-\mathrm{NH}_{2}$ and $-\mathrm{C}=\mathrm{O}$. GLU1, PRO2, ASP3, GLU4, and LEU6, and the molecular docking proved their participation in the chelating with Zn(II).
\end{abstract}

(C) 2020 International Association of Dietetic Nutrition and Safety. Publishing services by Atlantis Press International B.V. This is an open access article distributed under the CC BY-NC 4.0 license (http://creativecommons.org/licenses/by-nc/4.0/).

\section{INTRODUCTION}

Zinc is an important mineral that is involved in physiological metabolism, and functions in more than 300 metalloenzymes as a catalytic component ensuring the structural integrity of proteins [1]. Moreover, zinc has a vital influence on the immune system, as it is required for the activation of different kinds of immune cells [2]. Besides, zinc plays an important role in maintaining cell reproduction, gene expression, regulatory function, neurogenesis and neurotransmission $[3,4]$. But zinc cannot be synthesized in the body, and human zinc reserves are limited. Therefore, biological zinc must be continuously supplied from the individuals diet [5]. Zinc deficiency can seriously affect the immune system and destroy the redox balance of the body, leading to immune dysfunction, neurological decline, and the occurrence of some pathological diseases [6].

At present, zinc can be obtained from mineral salts and metal chelating agents [7]. However, mineral salts have poor bioavailability due to the inhibition of dietary components such as tannins, phytates, and dietary fibers $[8,9]$. Therefore, it is necessary to develop alternatives that can improve the bioavailability of zinc. Subsequently, more attention has been paid to the study of new supplements of zinc, such as zinc-binding proteins or peptides as functional food.

Pioneering studies have shown that expressed proteins bear metal-coordinating side chains or incorporate such groups [10],

"Corresponding author. Email: yuanque@163.com

Peer review under responsibility of the International Association of Dietetic Nutrition and Safety and the same applies to food-derived peptides. A great number of food-derived peptides with metal chelating abilities have been identified such as the sesame protein [11], whey protein [12], milk protein [13], Antarctic krill protein [14], amyloid protein [15] and walnut protein [16]. Furthermore, food-derived peptides can be easily digested and absorbed due to having a small molecular weight and a simple structure. However, the activity of the walnut-derived polypeptide with zinc chelation has been hardly reported.

The study presented here demonstrates the structure-activity relationship of $\mathrm{Zn}$ (II) and walnut-derived polypeptides share after chelation. In our team's previous research, several peptides were isolated and identified from walnut protein. Among them, Glu-ProAsn-Gly-Leu-Leu-Leu-Pro-Gln-Tyr (WP-10) showed metal ion chelating activity. The aim of this study was to prepare zinc-chelating peptides (purified synthetic walnut-derived polypeptides) and provide the theoretical basis behind using zinc-chelating peptides from walnut protein as a functional food ingredient.

\section{MATERIALS AND METHODS}

\subsection{Materials and Chemicals}

The walnut peptide WP-10 was synthesized from Cellman Biotech Limited Corporation (Hefei, China). Zinc chloride buffer solutions of varying $\mathrm{pH}$ levels and all other reagents were purchased from Damao Chemical Reagent Co. Ltd. (Tianjin, China). 


\subsection{Preparation of the Zinc-Chelating Peptide}

WP-10 (0.2 $\mathrm{mmol} / \mathrm{mL})$ was dissolved in a Tris-HCl buffer ( $0.05 \mathrm{~mol} / \mathrm{L}$, pH 5.0) containing $\mathrm{ZnCl}_{2}$. The centrifuge tube containing the mixture was placed in a constant temperature shaking water bath at $47^{\circ} \mathrm{C}$ for $80 \mathrm{~min}$. After that, the free zinc ion was removed by dialysis for $24 \mathrm{~h}$ using a $100 \mathrm{Da}$ molecular weight dialysis bag made of semi-permeable membrane, and collected retentates (containing chelated zinc). Additionally, a part of it was lyophilized as a complete chelate for the following study.

\subsection{Zinc Chelating Capacity Analysis}

The free zinc content in the supernatant was evaluated by flame atomic absorption spectrometry (ZA3000, HITACHI, Japan) according to $\mathrm{Wu}$, Wenfei and Smichowski's methods with some modifications $[17,18]$, the chelated zinc content was calculated. The experiments were performed in triplicates and data was presented as the mean of each repeated experiment.

\subsection{Ultraviolet-Visible Spectroscopy}

In order to testify the occurrence of the zinc-chelating peptide reaction and investigate the functional mechanism between the peptide and peptide-zinc chelates, the absorbance values were recorded in the wavelength range from 200 to $1100 \mathrm{~nm}$ with an Ultraviolet-Visible (UV-Vis) spectrophotometer (F-2700, HITACHI, Japan). The zinc-chelating peptide and pure peptide were dissolved in a $0.1 \mathrm{~mol} / \mathrm{L}$ Tris- $\mathrm{HCl}$ buffer $(\mathrm{pH} 7.4)$. Besides, samples were put in a quartz cuvette with a path length of $0.5 \mathrm{~cm}[19-21]$.

\subsection{Circular Dichroism Spectroscopy}

The secondary structure of the zinc-chelating peptide and pure peptide was investigated with a circular dichroism (CD) spectrophotometer (J-1500, Jasco, Japan) and the zinc-chelating peptide was compared to the pure peptide. The spectra of the zinc-chelating peptide and pure peptide were recorded in the wavelength range from 190 to $260 \mathrm{~nm}$ with a scanning rate of $20 \mathrm{~nm} / \mathrm{min}$, and a $1 \mathrm{~nm}$ bandwidth. In these experiments, the data was represented as the average of three independent scans with the control CD signal subtracted [22].

\subsection{Fourier Transform Infrared Spectroscopy}

The zinc-chelating peptide and pure peptide were inspected by Fourier Transform Infrared Spectroscopy (FTIR) (Frontier, Perkin Elmer, USA). One milligram of the sample was mixed with $100 \mathrm{mg}$ of dried $\mathrm{KBr}$, pulverized in an agate mortar, and then pressed into a transparent round shape [23]. The spectra were recorded in the wavenumber region of $4000-400$ per $\mathrm{cm}$ with a resolution of 4 per $\mathrm{cm}$ and an average scan of 16 times [24]. The potential zinc-chelating sites were deduced from the significant shifts in absorption bands [16].

\subsection{Molecular Dynamics Simulation}

The discovery Studio 2017 R2 software with minor modifications was used to conduct molecular docking between WP-10 and zinc ions. The amino acid sequence of peptides was entered and the peptide structure was pretreated with the Prepare Protein tool. The structures of the ligands were generated by the DS 2017 R2 software and the Full Minimization tool was utilized to give the minimized energy. The peptide structure was processed with the clean and prepare protein program to model missing loop regions, remove water, add hydrogen, and optimize the bond length. The docking sites have a spherical center with a center diameter of $8 \AA$ as the active site to cover the docking region. The docking program was carried out using the partial flexibility program CDOCKER protocol. Evaluation of molecular docking results was based on CDOCKER energy scores, interaction sites, and interaction force types $[25,26]$.

\section{RESULTS AND DISCUSSION}

\subsection{Zinc Chelating Capacity of Peptide}

Zinc chelating capacity of peptide was shown in Figure 1. The amount of chelated $\mathrm{Zn}$ (II) on the WP-10 increased when the concentration of $\mathrm{Zn}$ (II) increased. The zinc chelating capacity did not increase significantly when zinc concentration reached $1.5 \mu \mathrm{mol} / \mathrm{L}$. The reason may be that it is already saturated. Therefore, zinc ion concentration was one of the most important factors affecting the chelating capacity.

\subsection{Ultraviolet-Visible Spectroscopy Analysis}

As the curve shown in Figure 2, there are peaks in 280 and $220 \mathrm{~nm}$, respectively as determined by the intensity and dislocation change of UV-Vis spectroscopy. As we all know, Tyrosine (Tyr) can absorb

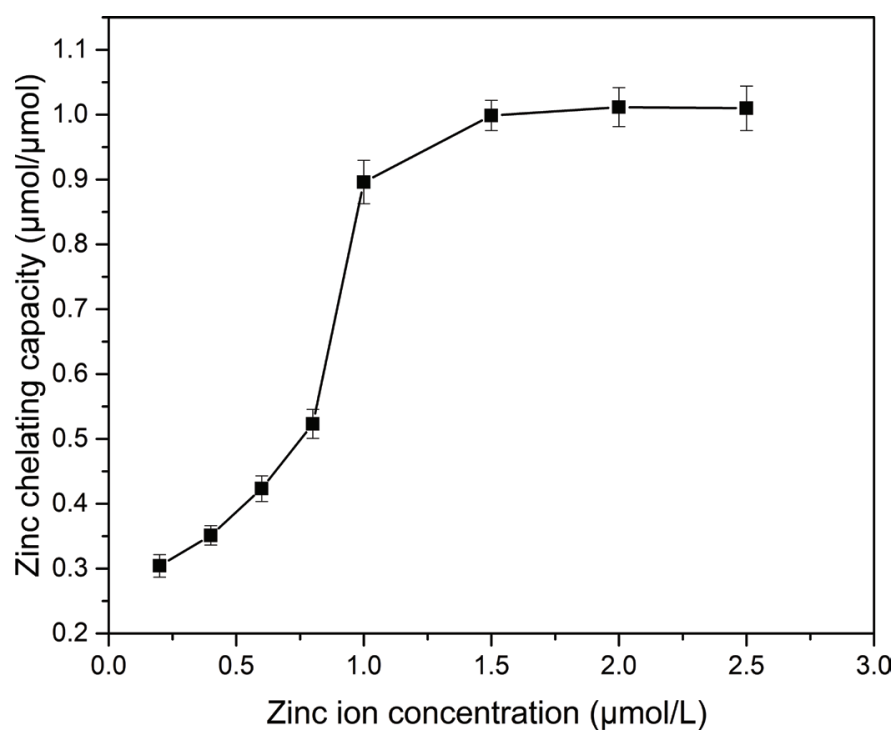

Figure 1 Effects of zinc ion concentration on zinc chelating capacity. The zinc chelating capacity was determined by flame atomic absorption spectrometry. All the samples were determined three times and the data were reported as mean \pm SD. 
ultraviolet light at $278 \mathrm{~nm}$, Tryptophan (Trp) can absorb ultraviolet light at $279 \mathrm{~nm}$, Phenylalanine (Phe) can absorb ultraviolet light at $259 \mathrm{~nm}$. The peak detected in $280 \mathrm{~nm}$ was small, which was attributed to lack of Phe, Tyr and Trp. After chelating interactions, the peak value slightly reduced, which was explained by the facts that some of Tyr in WP-10 were buried after chelation with $\mathrm{Zn}$ (II). These results were corresponded to the results of Figure 1. As for the peaks in $220 \mathrm{~nm}$, it also decreased after chelating. It indicated that WP-10 were chelated to $\mathrm{Zn}$ (II) and the content of free peptides was decreased.

\subsection{Circular Dichroism Spectroscopy Analysis}

In circular dichroism spectrum analysis, if a negative peak ranged between 190 and $220 \mathrm{~nm}$, it indicates that the peptide has a random structure. Similar results were found as for $\beta$-sheet structure, when negative peak ranges from 210 to $225 \mathrm{~nm}$. As shown in Figure 3, the curve of circular dichroism spectrum for WP-10 had a negative

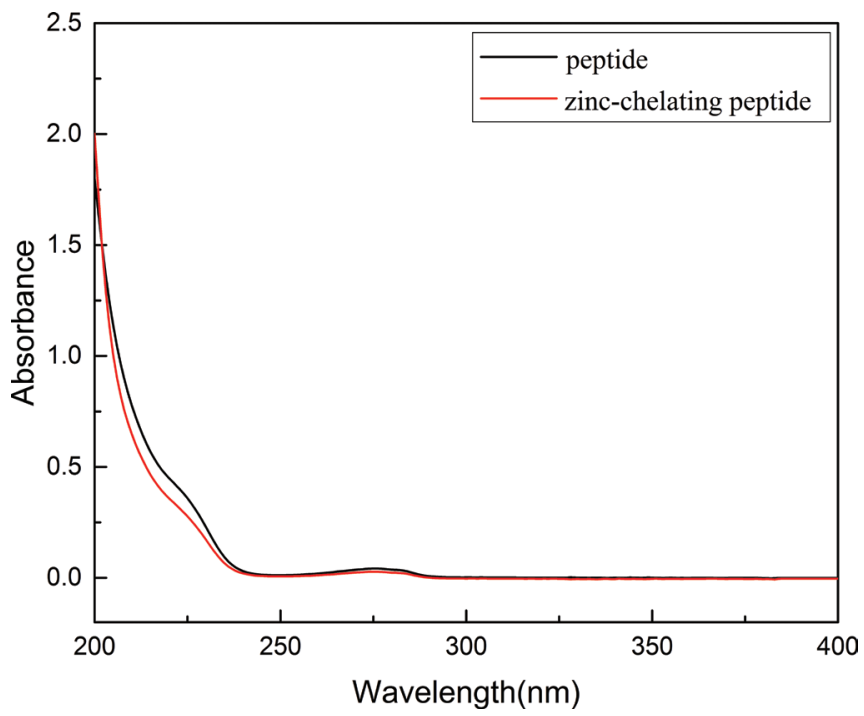

Figure $2 \mid \mathrm{UV}-$ Vis spectrum of the decapeptide and zinc-chelating peptide. The WP-10 and zinc-chelating peptide were dissolved in Tris$\mathrm{HCl}$ buffer $(0.1 \mathrm{~mol} / \mathrm{L}, \mathrm{pH}$ 7.4). The spectra were recorded between 200 and $1100 \mathrm{~nm}$ with a scan speed of $20 \mathrm{~nm} / \mathrm{min}$. peak at $190-225 \mathrm{~nm}$. Therefore, it may have $\beta$-sheet and random structures. Moreover, it could be found that WP- 10 contains mostly the structure of random and $\beta$-sheet which was $79.6 \%$ and $20.4 \%$ in the peptide, respectively.

When the WP-10 was chelated with $\mathrm{Zn}(\mathrm{II})$, its molecular structure changed accordingly. It could be found that a positive peak ranged from 190 to $195 \mathrm{~nm}$ while a negative peak from 195 to $220 \mathrm{~nm}$, which indicated that $\alpha$-helix and $\beta$-turn presented after WP-10 chelated with $\mathrm{Zn}(\mathrm{II})$, while $\beta$-sheet disappeared. The proportions of $\alpha$-helix, $\beta$-turn and random structures were $18.5 \%, 17.8 \%$, and $63.8 \%$, respectively.

Compared to these two results, it was verified that the effect of $\mathrm{Zn}$ (II) on the structure of WP-10 was consistent with the results of UV-Vis spectroscopy analysis. In a $\mathrm{Zn}$ (II) rich system, $\mathrm{Zn}$ (II) chelating WP-10 was a process that destroyed the $\beta$-sheet structure and reconstituted it to $\alpha$-helix and $\beta$-turn in WP-10 resolution. In this process, a part of random structures was involved in this conversion.

\subsection{Fourier Transform Infrared Spectroscopy Analysis}

As shown in Figure 4, the wave number (WN) region of infrared spectrogram (IR) fingerprint spectrum was ranged from 650 to 1350 per $\mathrm{cm}$. It could be found that the waveforms of WP-10 and zinc-chelating peptide complexes were significantly different while waveforms among the chelated peptides in different $\mathrm{Zn}$ (II) concentration were similar. These fingerprint spectrums could be used to distinguish this peptide whether chelated with $\mathrm{Zn}$ (II) or not. Combined with Figures 1 and 2, the IR and structure of the pure peptide, the peaks of functional groups, such as $\mathrm{C}-\mathrm{C}(\mathrm{O}), \mathrm{NH}$, $\mathrm{RNH}_{2},-\mathrm{CH},-\mathrm{CH}_{3}, \mathrm{C}=\mathrm{O}$, could be identified. The amide-I vibration $(\mathrm{C}=\mathrm{O}$ stretching vibration, $1690-1630$ per $\mathrm{cm}$ ) and amide-II vibration $(\mathrm{N}-\mathrm{H}$ bending $(40-60 \%)$ and $\mathrm{C}-\mathrm{N}$ stretching vibrations (18-40\%), 1655-1590 per $\mathrm{cm}$ ) were the most dominant vibrational modes of amides [27]. The peak of $\mathrm{C}=\mathrm{O}$ in 1650 per $\mathrm{cm}$ disappeared after chelation. It indicated that the oxygen atom of $\mathrm{C}=\mathrm{O}$ may be chelated with $\mathrm{Zn}(\mathrm{II})$. The peaks of $\mathrm{RNH}_{2}$ and $\mathrm{NH}$ in 3450 and 3300 per $\mathrm{cm}$ shifted to high WN respectively, blue-shift. According to the structure of WP-10, this may be because the nitrogen atom of $\mathrm{RNH}_{2}$ and $\mathrm{NH}$ was chelated with $\mathrm{Zn}$ (II) leading to the increase of electronegativity around the nitrogen atom. The peaks of

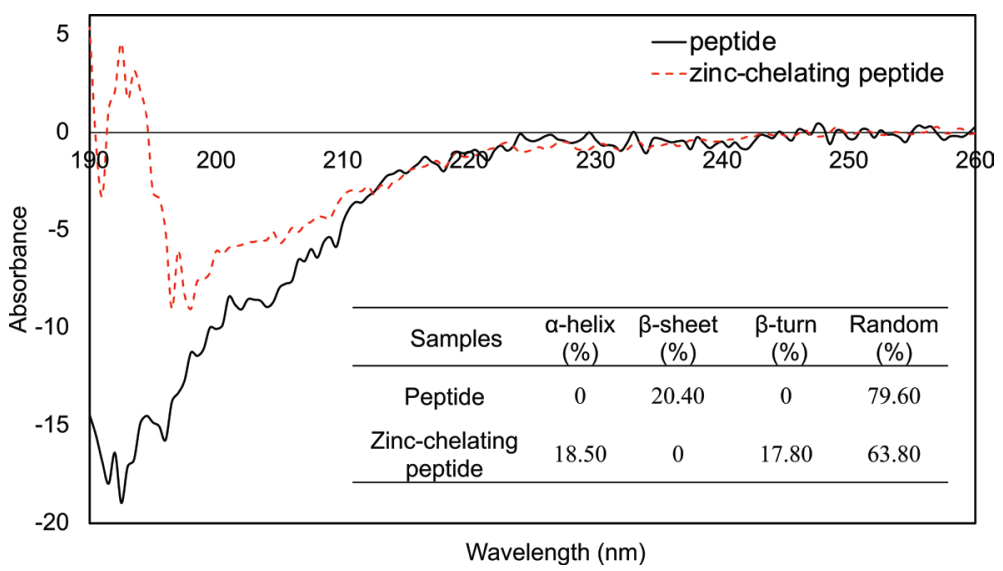

Figure $3 \mathrm{CD}$ spectrum of the decapeptide and zinc-chelating peptide. The WP-10 and zinc-chelating peptide were dissolved in Milli-Q water to a final concentration of $0.20 \mathrm{mmol} / \mathrm{mL}$. The spectra were recorded between 190 and $260 \mathrm{~nm}$ with a scan speed of $20 \mathrm{~nm} / \mathrm{min}$. 


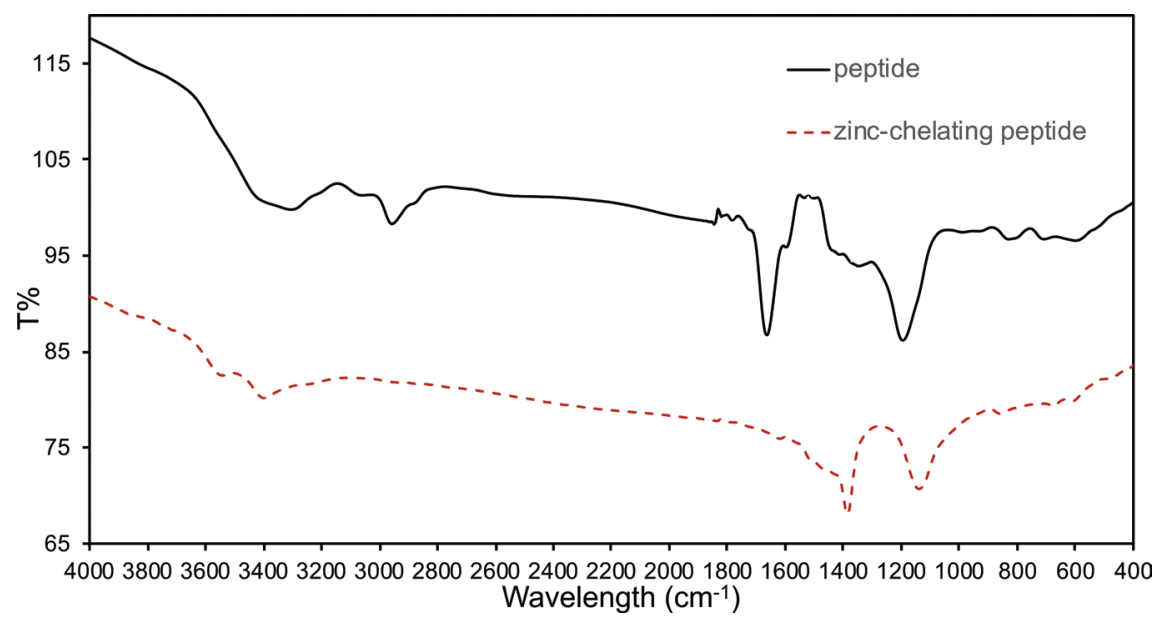

Figure 4 Infrared spectrogram of the decapeptide and zinc-chelating peptide. The spectra were recorded between 4000 and 400 per $\mathrm{cm}$ at a resolution of 4 per $\mathrm{cm}$ with an average of 16 scans.

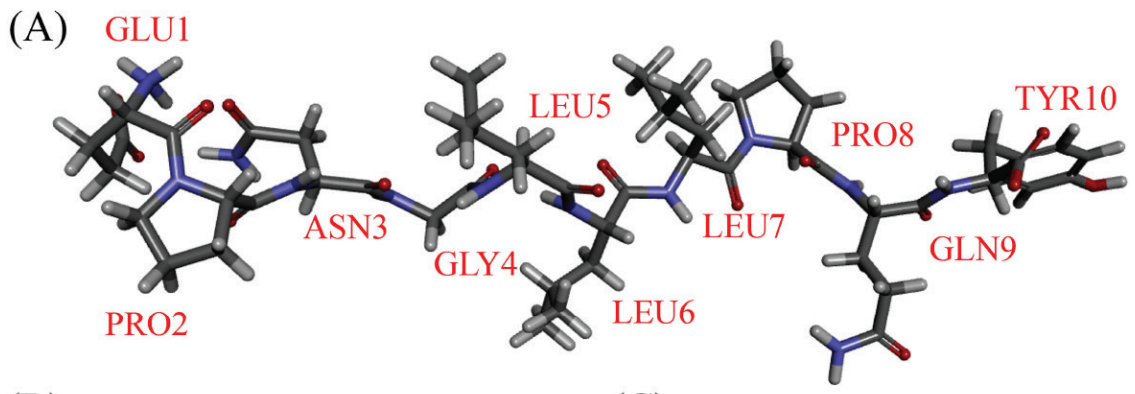

(B)

(D)
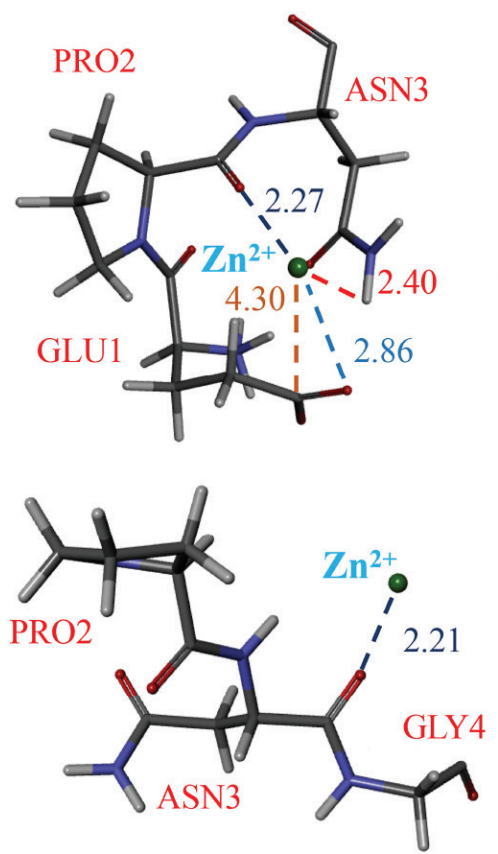

(C)

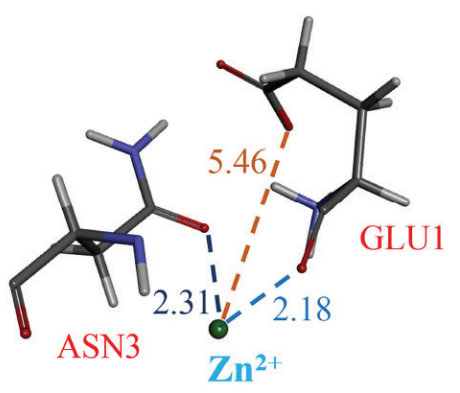

(E)

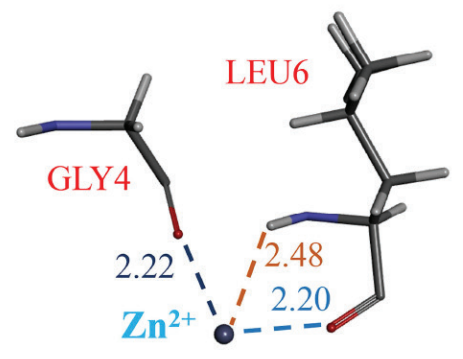

Figure 5 Molecular docking simulation of peptide chelated with zinc. (A) was the structure of peptide after energy minimization. (B-E) were the chelation sites.

$\mathrm{C}-\mathrm{C}(\mathrm{O})$ in 1200 per $\mathrm{cm}$, represented aromatic acyl halide, shifted to low $\mathrm{WN}$, known as red-shift. It is owing to the presence of the phenolic hydroxyl group of the tyrosine forming the hydrogen bond. This result confirmed that the absorption value of UV decreased at $220 \mathrm{~nm}$ and $280 \mathrm{~nm}$ after chelation. The FTIR spectra of peptide-zinc(II) complex in walnut showed similar changes [16].

\subsection{Molecular Dynamic Simulation of Zinc-Chelating Peptide}

Molecular docking predicts the interactions between ligands and receptors by calculating interaction such as interaction energies, binding sites, and other information. As shown in Figure 5, the 


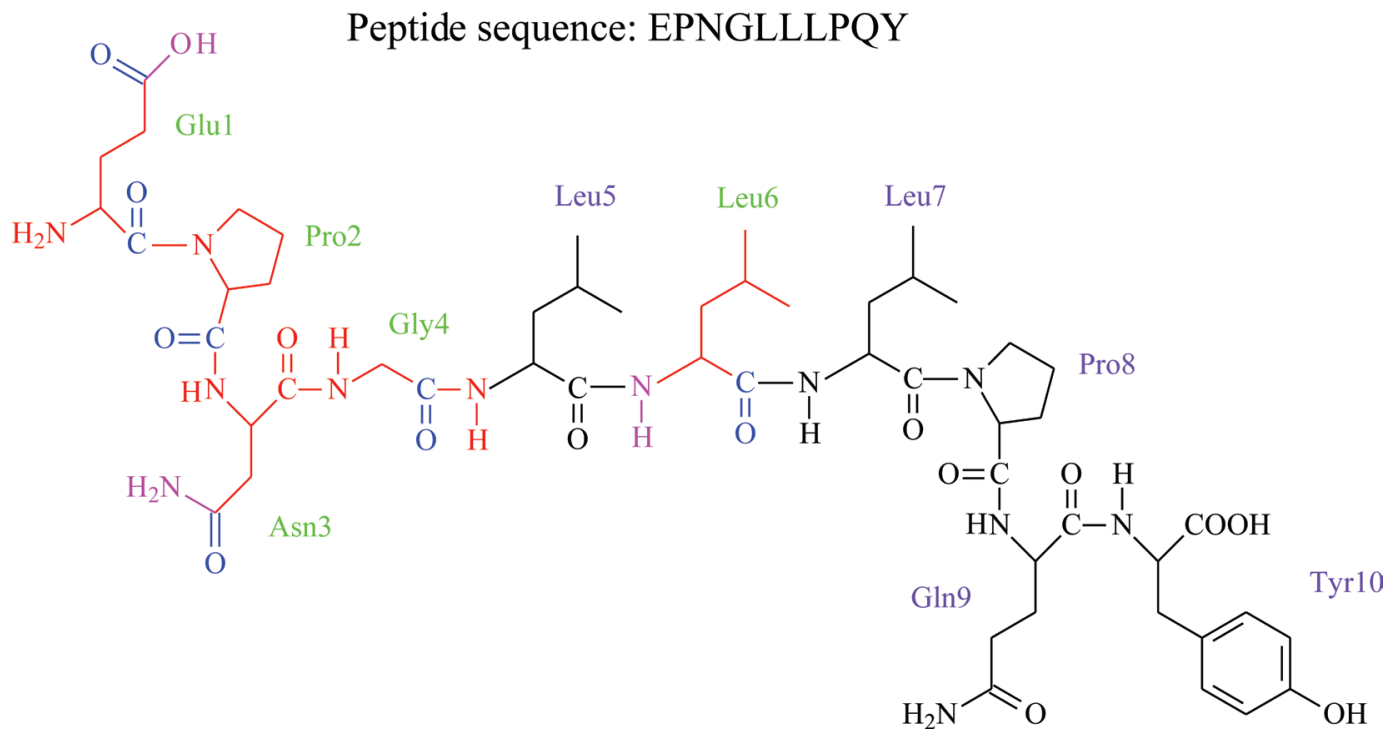

Figure 6 The chemical structure diagram of peptide. The structures marked with red color were represented the amino acids that participated in the chelation (marked with green name). The structures marked with black color were represented the amino acids that do not participated in the chelation (marked with purple name). The groups marked with blue color were represented the functional groups that participated in the chelation. The groups that may affect the chelation results were marked with pink color (repulsive force).

structure of WP-10 after energy minimization was used to simulate the docking of $\mathrm{Zn}(\mathrm{II})$. The docking results indicated that there were four possible binding sites of $\mathrm{Zn}(\mathrm{II})$ in WP-10. GLU1, PRO2, and ASN3 $\left(\mathrm{G}_{\mathrm{LU}} \mathrm{P}_{\mathrm{RO} 2} \mathrm{~A}_{\mathrm{SN} 3}\right)$ formed one of sites. GLU1 and ASN3 $\left(\mathrm{G}_{\mathrm{LU1}} \mathrm{A}_{\mathrm{SN} 3}\right)$ formed one site. ASN3 $\left(\mathrm{A}_{\mathrm{SN} 3}\right)$ formed another site, while GLY4 and LEU6 $\left(\mathrm{G}_{\mathrm{LY} 4} \mathrm{~L}_{\mathrm{EU} 6}\right)$ form the last one. However, the chelation strength is different at different sites. The conclusion was also demonstrated in Figure 1.

In Figure 6, the functional groups that play a major role in chelation was shown. As to WP-10, carbonyl group was the main functional groups interacting with $\mathrm{Zn}$ (II). The hydroxy group of GLU1 and the amidogen of ASN3 and LEU6 also could affect the chelation. According to these results, the structure of WP-10 could be changed and combined by site-specific mutagenesis for further application.

\section{CONCLUSION}

The WP-10 has an outstanding Zn(II) binding affinity. There are four sites in WP-10 that could bind with $\mathrm{Zn}$ (II) in $\mathrm{Zn}$ (II) rich environments. The maximal ratio of WP-10 chelated with $\mathrm{Zn}$ (II) was 1:1. GLU1, PRO2, ASN3, GLY4, and LEU6 were the main amino acids to form the chelation sites. The main groups involved in chelation were carbonyl groups. Some of the hydroxyl and amidogen groups also contribute to the chelation. The results from this study indicate that it is feasible to produce natural metal chelating using WP-10 peptides from walnut protein.

\section{CONFLICTS OF INTEREST}

The authors declare they have no conflicts of interest.

\section{AUTHORS' CONTRIBUTION}

WF contributed in writing original draft preparation. LJ and HRE contributed in writing review and editing. MD and CW contributed in supervision. ZW and ZM contributed in funding acquisition.

\section{ACKNOWLEDGMENTS}

This study was financially supported by the Basic Research Program of Liaoning Education Department (2017J080) and the National Natural Science Foundation of China (31371805).

\section{REFERENCES}

[1] McCall KA, Huang C, Fierke CA. Function and mechanism of zinc metalloenzymes. J Nutr 2000;130:1437S-46S.

[2] Prasad AS. Discovery of human zinc deficiency: 50 years later. J Trace Elem Med Biol 2012;26:66-9.

[3] Maret W, Sandstead HH. Zinc requirements and the risks and benefits of zinc supplementation. J Trace Elem Med Biol 2006;20:3-18.

[4] Hambidge M. Human zinc deficiency. J Nutr 2000;130; 1344S-9S.

[5] El-Din AMG, Hassan ASH, El-Behairy SA, Mohamed EA. Impact of zinc and iron salts fortification of buffalo's milk on the dairy product. World J Dairy Food Sci 2012;7:21-7.

[6] Aquilanti L, Kahraman O, Zannini, E, Osimani, A, Silvestri, G, Ciarrocchi, F, et al. Response of lactic acid bacteria to milk fortification with dietary zinc salts. Int Dairy J 2012;25:52-9.

[7] Hurrell R. How to ensure adequate iron absorption from ironfortified food. Nutr Rev 2002;60:S7-S15. 
[8] Lee SH, Song KB. Purification of an iron-binding nona-peptide from hydrolysates of porcine blood plasma protein. Process Biochem 2009;44:378-81.

[9] Lönnerdal B. Dietary factors influencing zinc absorption. J Nutr 2000; $130: 1378$ S-83S.

[10] Tavenor NA, Murnin MJ, Horne WS. Supramolecular metalcoordination polymers, nets, and frameworks from synthetic coiled-coil peptides. J Am Chem Soc 2017;139:2212-15.

[11] Wang C, Li B, Ao J. Separation and identification of zinc-chelating peptides from sesame protein hydrolysate using IMAC- $\mathrm{Zn}^{2+}$ and LC-MS/MS. Food Chem 2012;134:1231-8.

[12] Udechukwu MC, Downey B, Udenigwe CC. Influence of structural and surface properties of whey-derived peptides on zincchelating capacity, and in vitro gastric stability and bioaccessibility of the zinc-peptide complexes. Food Chem 2018;240:1227-32.

[13] Rana B, Kaushik R, Kaushal K, Arora S, Kaushal A, Gupta S, et al. Physicochemical and electrochemical properties of zinc fortified milk. Food Biosci 2018;21:117-24.

[14] Hou H, Wang S, Zhu X, Li Q, Fan Y, Cheng D, et al. A novel calcium-binding peptide from Antarctic krill protein hydrolysates and identification of binding sites of calcium-peptide complex. Food Chem 2018;243:389-95.

[15] Faller P, Hureau C, La Penna G. Metal ions and intrinsically disordered proteins and peptides: from $\mathrm{Cu} / \mathrm{Zn}$ amyloid- $\beta$ to general principles. Acc Chem Res 2014;47:2252-9.

[16] Liao W, Lai T, Chen L, Fu J, Sreenivasan ST, Yu Z, et al. Synthesis and characterization of a walnut peptides-zinc complex and its antiproliferative activity against human breast carcinoma cells through the induction of apoptosis. J Agric Food Chem 2016;64:1509-19.

[17] Wu W, Li B, Hou H, Zhang H, Zhao X. Isolation and identification of calcium-chelating peptides from Pacific cod skin gelatin and their binding properties with calcium. Food Funct 2017;8:4441-8.

[18] Smichowski P, Londonio A. The role of analytical techniques in the determination of metals and metalloids in dietary supplements: a review. Microchem J 2018;136:113-20.
[19] Wang X, Gao A, Chen Y, Zhang X, Li S, Chen Y. Preparation of cucumber seed peptide-calcium chelate by liquid state fermentation and its characterization. Food Chem 2017;229: 487-94.

[20] Huang SL, Zhao LN, Cai X, Wang SY, Huang YF, Hong J, et al. Purification and characterisation of a glutamic acid-containing peptide with calcium-binding capacity from whey protein hydrolysate. J Dairy Res 2015;82:29-35.

[21] Chen D, Liu ZY, Huang WQ, Zhao YH, Dong SY, Zeng MY. Purification and characterisation of a zinc-binding peptide from oyster protein hydrolysate. J Funct Foods 2013;5:689-97.

[22] Nakatsuka N, Barnaby SN, Tsiola A, Fath KR, Williams BA, Banerjee IA. Self-assembling peptide assemblies bound to ZnS nanoparticles and their interactions with mammalian cells. Colloid Surf B Biointerfaces 2013;103:405-15.

[23] Zhang Z, Zhou F, Liu X, Zhao M. Particulate nanocomposite from oyster (Crassostrea rivularis) hydrolysates via zinc chelation improves zinc solubility and peptide activity. Food Chem 2018;258:269-77.

[24] Hajji L, Boukir A, Assouik J, Kerbal A, Kajjout M, Doumenq P, et al. A multi-analytical approach for the evaluation of the efficiency of the conservation-restoration treatment of Moroccan historical manuscripts dating to the 16th, 17th, and 18th centuries. Appl Spectrosc 2015;69:920-38.

[25] Vats C, Dhanjal JK, Goyal S, Bharadvaja N, Grover A. Computational design of novel flavonoid analogues as potential AChE inhibitors: analysis using group-based QSAR, molecular docking and molecular dynamics simulations. Struct Chem 2015;26:467-76.

[26] Fu Y, Alashi AM, Young JF, Therkildsen M, Aluko RE. Enzyme inhibition kinetics and molecular interactions of patatin peptides with angiotensin I-converting enzyme and renin. Int J Biol Macromol 2017;101:207-13.

[27] Zhou J, Wang X, Ai T, Cheng X, Guo HY, Teng GX, et al. Preparation and characterization of $\beta$-lactoglobulin hydrolysateiron complexes. J Dairy Sci 2012;95:4230-6. 